\title{
ASSESSMENT OF ORGANIC FERTILIZER USAGE BY VEGETABLE FARMERS IN ASA LOCAL GOVERNMENT AREA OF KWARA STATE, NIGERIA
}

\author{
Aderinoye-Abdulwahab, S. A., \& Salami, S. T. \\ Department of Agricultural Extension \& Rural Development, University if Ilorin, Nigeria \\ E-mail: sidiay@yahoo.com
}

\begin{abstract}
Vegetables support rural and urban population both in terms of subsistence and income generation. Its cultivation however presents with problems that can be reduced with the use of organic fertilizers. Therefore, there is a need to assess the use of organic fertilizer among vegetable growers as it directly affects yield of vegetables. This study was conducted in Asa Local Government Area of Kwara State. Purposive and simple random sampling was used to select 120 respondents who were interviewed. Results from the study showed that the majority of the respondents (94\%) were above 25 years while $77 \%$ of the farmers were females. A few number of the respondents (19\%) had secondary education while many (50\%) lack formal education. A large proportion (86\%) of the respondents use organic fertilizer on their farms and $72 \%$ use a combination of poultry droppings and cow-dung to fertilize their farms on a regular basis (fortnightly). Offensive odour and transportation problems were among the prominent limitations to the use of organic fertilizer among the farmers. The study concludes that although vegetable farmers in the study area profusely use organic fertilizer, the yield is rather poor. It was therefore recommended that application should be supervised by relevant agencies to ensure correct levels of usage whilst research institutes need to devise means of reducing offensive smells of organic fertilizers.
\end{abstract}

Keywords: Organic fertilizer, Vegetable production, Yield, offensive odour.

\section{INTRODUCTION}

Fertilizer is defined, according to the international fertilizer industry association as materials containing five percent of more of the three essential plant nutrients (Adrian et al., 2014). Fertilizers are soil amendments that guarantee the minimum percentages of Nitrogen, Phosphate and Potash (Adrian et. al. 2014). The goal of applying fertilizer on plants is to make them grow faster by supplying the elements that are needed in readily available forms. 
Fertilizers are of two major types, that is, organic fertilizer made from animal matter, human excreta or vegetable matter and inorganic fertilizer made from synthetic materials (Heinrich et al. 2009). The advantages of fertilizer include: increasing crop yield and improving the quality of the land, improving soil texture and faster growth of crops (EPA, 2013). Their disadvantages include: boosting fast growth of weeds, Excessive use has negative environmental effects such as contamination of water (nearby rivers and water supply system) and reducing the oxygen content in water making the water unfit for consumption and causing the death of Aquatic animals (Wilfred, 2002), soil acidification and changes in soil biology (Carroll and Salt, 2004).

Given that the most important natural resource is the soil, it is important to preserve the humus top soil and maintain or increase its organic matter content to increase the nutrient providing ability and to carry on an environment-friendly nutrient management (Rigby and Ca'ceres, 2001 and Defoer, 2002). In order for this to be achieved, the use of organic fertilizer is important the accumulation of the use of inorganic fertilizers results in soil structure destruction, environmental pollution by contaminating the soil and water in the environment.

Vegetable plant parts are either eaten fresh or prepared in a number of ways. Vegetables tend to have short production cycles, receive intensive labour but few purchased inputs and produce high yields with strong nutritional value (Obalola and Tanko, 2016). They support rural and urban populations both in terms of subsistence and income generation without requiring large capital investments. It is estimated that there are at least ten thousand plant species used as vegetables worldwide but only about fifty of them are of great commercial value (Shing-Jy and Hsiao-Feng, 2003). The vegetables generally cultivated in Africa, most especially the tropics are of the genera: Amaranthus, Celosia, Cucumis, Hibiscus, Talinum, Solanum and Corchorus with onion, tomato, okra, pepper, amaranthus, carrot, melon, and Jute (Tindall, 1983 and Ibeawuchi et al., 2015).

Vegetables are generally associated with a number of problems particularly from the production aspect. The use of inorganic fertilizers on farms can cause problems of serious soil degradation, increased soil acidity and nutrient imbalance and finally bringing about low yield but the use of organic fertilizer can help in protecting the soil from the listed adverse effects. Despite the use of organic fertilizers by many vegetable farmers, it has been observed that in the year 2011, 1087.59 million tonnes of vegetable was produced in the world and Africa produced 67.85 million tonnes of that figure (FAO, 2011); this is not enough to solve the problem of inadequate nutritional benefits to meet the populace's nutritional 
demands. Although, the use of organic fertilizer is being advocated for because of its soil conservation property and its eco-friendliness over the inorganic fertilizer, and it is mainly the source adopted by vegetable farmers to supply nutrients for their vegetables to enhance growth and yield, nonetheless, there has not been an increase in the amount of vegetables supply to the populace (Verena et. al., 2012). Therefore, there is a need to assess the effectiveness of organic fertilizer as it directly affect yield of vegetables and helps to conserve the soil. The general objective of this study was to assess the use of organic fertilizer by vegetable farmers in Asa Local Governement Area (LGA) of llorin, Kwara State while the specific objectives of the study were to identify the extent to which vegetable farmers use organic fertilizer, identify the amount of vegetables produced in the study area and determine the constraints affecting the use of organic fertilizers in the study area. The study tested if there is a significant relationship between the socio-economic characteristics of farmers and the extent of use of organic fertilizer by vegetable farmers. The study would help to ensure that farmers' vegetable yield is optimum while also securing maximum profits for farmers as well as improved farming standards through soil conservation.

\section{METHODOLOGY}

Study Area: This study was carried out in Asa LGA of Kwara state, Nigeria. The area has a land mass of 1, 286 square kilometers with a population of 126, 435 (NPC, 2006). The area was chosen because it is predominantly known for vegetable farming.

Population of the Study: The population of the study comprised all vegetable farmers in the study area.

Sampling technique and sample size: Data for the study were obtained through a threestage sampling technique. In the first stage, Asa LGA was purposively selected from the Local Governments in Kwara State due to its prominence in vegetable farming; the local government consists of three districts, including: Afon, Owode and Onire. In the second stage, six (6) communities were randomly selected from the districts in the local government area, they are: Lasoju, Afon, Budo-Egba, Igboroko, Otte and Alapa. In the third stage, twenty (20) vegetable farmers were randomly selected from each of the six communities to give a total sample size of 120 respondents. Questionnaire was used to elicit information from the 120 respondents using an interview schedule format and observations of the researcher on the field. 
Data Analysis: Data for the study was analyzed through simple frequency, percentages and mean and Pearson product Moment Correlation.

\section{RESULTS AND DISCUSSION}

\section{Socio-economic characteristics of the vegetable farmers}

The results show that only $6.7 \%$ of the vegetable farmers are below $25 y$ years old, about $47 \%$ are within the age range of $25-35$ years, while the remainder (47\%) are above 45 years. The mean age of the respondents was 43 years (Table 1). This implies that older people tend to be more involved in vegetable production in the study area. The result also shows that the minimum age of the respondents was below 25 years. This also suggest that in as much as older people are involved in vegetable farming, there are still a few of the younger generation involved in vegetable farming. On the other hand, the oldest of the sample was above 56 years. This age further shows that vegetable farming in Asa LGA is the domain of adults. Adebayo and Adekunle (2016) also reported that the gender of an individual can influence the type and quality of work carried out by the individual. The results obtained showed that there were more females (77.5\%) involved in vegetable farming than their male $(22.5 \%)$ counterpart in the study area.

In traditional agricultural production, the amount of family labour available is usually closely related to the marital status of the farmer. Table 1 thus reveals that majority of the sample are married (84.2\%). Therefore, they are more likely to have familial responsibility such as having families to cater for and this also suggests that the married farmers in the study area might have a reasonable family size providing more family labour compared to those farmers who are unmarried. A farmer's level of education is expected to influence his innovativeness and ability to make decisions on various aspects of farming. As shown in Table 1,50.8\% of the farmers have no formal education, 30\% attained primary education while $19.2 \%$ attended secondary school and this is the highest educational level attained amongst the sample. 
Table 1: Socio-economic characteristics of Vegetable Farmers in Asa LGA, llorin

\begin{tabular}{|c|c|c|c|}
\hline Variables & Frequency $(n=120)$ & Percentage (\%) & Mean \\
\hline \multicolumn{4}{|l|}{ Age } \\
\hline$\leq 25$ years & 8 & 6.7 & \\
\hline $26-35$ years & 32 & 26.7 & \\
\hline $36-45$ years & 25 & 20.8 & 43.4 \\
\hline $46-55$ years & 34 & 28.3 & \\
\hline$\geq 56$ years & 21 & 17.5 & \\
\hline \multicolumn{4}{|l|}{ Gender } \\
\hline Male & 27 & 22.5 & \\
\hline Female & 93 & 77.5 & \\
\hline \multicolumn{4}{|l|}{ Marital status } \\
\hline Single & 11 & 9.2 & \\
\hline Married & 101 & 84.2 & \\
\hline Unmarried & 8 & 6.6 & \\
\hline \multicolumn{4}{|l|}{ Educational qualification } \\
\hline Primary education & 36 & 30.0 & \\
\hline Secondary education & 23 & 19.2 & \\
\hline Non-formal education & 61 & 50.8 & \\
\hline \multicolumn{4}{|l|}{ Years of experience } \\
\hline$\leq 10$ years & 34 & 28.3 & \\
\hline $11-30$ years & 70 & 58.4 & \\
\hline$\geq 30$ years & 16 & 13.3 & 19.1 \\
\hline \multicolumn{4}{|l|}{ Farm size } \\
\hline$\leq 1 \mathrm{ha}$ & 75 & 62.5 & \\
\hline $2-5$ ha & 42 & 35.0 & \\
\hline $6-10$ ha & 3 & 2.5 & 1.7 \\
\hline \multicolumn{4}{|l|}{ Household size } \\
\hline $1-5$ & 42 & 35.0 & \\
\hline $6-15$ & 77 & 64.1 & \\
\hline$\geq 16$ & 1 & 0.8 & 6.0 \\
\hline \multicolumn{4}{|l|}{ Other crops planted } \\
\hline Cassava & 42 & 35.0 & \\
\hline Maize & 29 & 24.2 & \\
\hline Yam, Sorghum, Millet & 12 & 9.19 & \\
\hline Cassava, maize & 5 & 4.1 & \\
\hline Cassava, yam & 7 & 5.8 & \\
\hline Guinea corn, millet & 2 & 1.7 & \\
\hline Potato, sorghum, millet, yam & 23 & 39.3 & \\
\hline \multicolumn{4}{|l|}{ Secondary occupation } \\
\hline Trading & 65 & 54.2 & \\
\hline Tailoring & 11 & 9.3 & \\
\hline Okada riding & 8 & 6.6 & \\
\hline Hairdressing & 9 & 7.5 & \\
\hline Others & 27 & 22.5 & \\
\hline
\end{tabular}

Source: Field Survey, 2016 
These results show a low level of literacy among the respondents as similarly observed by other studies. For example; Matanmi et al. (2011) and Adebayo and Adekunle (2016) also found that the majority of their respondents had low formal education. It therefore implies that the vegetable farmers are likely to have much difficulty in understanding and adopting modern agricultural technologies and innovation.

It was further shown in Table 1 that $35 \%$ of the vegetable farmers have household sizes of 1 5 persons, $60.8 \%$ have between $6-10$ persons in their household. This result shows that the household sizes of vegetable farmers in the study area are relatively large. It is interesting to note that $0.8 \%$ of the farmers have families with up to 16 persons in their households. Nonetheless, the average household size is 6 persons which is typical of rural communities in Nigeria (NBS, 2006). Farming experience generally correlates with acquisition of improved skills in agricultural production. Thus it should not be difficult for the vegetable farmers in this study to be able to easily adopt the best practices in organic farming given that $58.4 \%$ of the farmers have vegetable farming experience of $11-30$ years. The average farming experience is 19 years and this further shows that the farmers would have acquired much experience in vegetable farming enterprise. Further findings show that majority $(62.5 \%)$ of the farmers have farm size of below 1 hectare (ha), hence they were small-scale farmers. The implication of this is that majority of the farmers may not have as much yield that would enhance growth and development.

Mixed cropping is common practice particularly for subsistence farmers. Hence it is not surprising that the result shows that $35 \%$ plant Cassava, while $24.2 \%$ cultivate maize and other crops alternatively. A reason for the mixed cropping could be to augment incomes from vegetable farming. The table also shows that the vegetable farmers engage in other forms of income generating activities such as trading and a few of the males (7.5\%) are involved in okada (motor cycle) riding.

\section{Use of organic fertilizer in the study area}

It is shown in Table 2 that majority of the vegetable farmers $(86.7 \%)$ in the study area use organic fertilizer. This is in consonance with Alimi et al. (2006) who found that organic fertilizer is the main source adopted by vegetable farmers to supply nutrients to their crops probably because they are a cheap source of nutrient to their crops thus reducing the cost of production. 
Table 2: The use of Organic fertilizer in the study area

\begin{tabular}{lcl}
$\begin{array}{l}\text { Response to the use of } \\
\text { organic fertilizer }\end{array}$ & Frequency & Percent (\%) \\
\hline Yes & 104 & 86.7 \\
No & 16 & 13.3 \\
Total & 120 & 100.0 \\
\hline
\end{tabular}

Source: Field survey, 2016

\section{Types of organic fertilizer used in the study area}

The most frequently used organic fertilizer by vegetable farmers is poultry droppings and cow dung combination $(72.1 \%)$ as shown in Table 3 . This is possibly because of proximity of some of the farms to poultry farms and ranches as well as easy access to poultry droppings and manure which are important for adoption of technology (Odhiambo and Madangini, 2008). Open-market fertilizer $(50.0 \%)$ is also used by the vegetable farmers in the study area, which is second only to the combination of poultry droppings and cow dung in use. This could be due to the fact that it could easily be purchased and the farmers would not have to go through the stress of transporting, composting, drying of manure and they would not have to deal with offensive odour. Farmyard manure (44.2\%) is used at a lower rate to open-market fertilizer. Furthermore, $29.8 \%$ of the respondents use only poultry droppings to supply nutrients to their crops. They probably get these poultry droppings from the chickens they rear. Compost manure $(27.9 \%)$ is fairly used by the respondents in the study area which could be due to the stress of composting manure or the lack of knowledge of composting.

Table 3: Types of organic fertilizer used in the study area

\begin{tabular}{|c|c|c|c|}
\hline \multirow[t]{2}{*}{ Types of organic fertilizer used } & \multicolumn{2}{|c|}{ Responses } & \multirow{2}{*}{$\begin{array}{c}\text { Ran } \\
\mathbf{k}\end{array}$} \\
\hline & $\mathrm{N}$ & Percent & \\
\hline 1. Poultry droppings and cow dung & 75 & $72.1 \%$ & $1^{\text {st }}$ \\
\hline 2. Open-market fertilizer & 52 & $50.0 \%$ & $2^{\text {nd }}$ \\
\hline 3. Kraal (farmyard) manure & 46 & $44.2 \%$ & $3^{\text {rd }}$ \\
\hline 4. Poultry droppings & 31 & $29.8 \%$ & $4^{\text {th }}$ \\
\hline 5. Compost manure & 29 & $27.9 \%$ & $5^{\text {th }}$ \\
\hline 6. Cattle dung & 27 & $25.9 \%$ & $6^{\text {th }}$ \\
\hline
\end{tabular}

Source: Field survey, 2016

${ }^{*}$ Multiple response 


\section{Extent of use of organic fertilizer in the study area}

It is shown in Table 4 that majority of the farmers in the study area apply organic fertilizer to their crops fortnightly $(81.7 \%)$ because vegetables are short duration crops and usually require constant and adequate nutrient supply. $13.5 \%$ of the farmers apply organic fertilizers biannually while only a minority $(4.8 \%)$ apply organic fertilizer seasonally probably because they plant long duration vegetables that need fertilizer application on few occasions and they can retain nutrients.

Table 4: Extent of use of organic fertilizer in the study area

\begin{tabular}{lcl}
$\begin{array}{l}\text { The level of use of organic } \\
\text { fertilizer }\end{array}$ & Frequency & Percent (\%) \\
\hline Seasonally & 5 & 4.8 \\
Fortnightly & 85 & 81.7 \\
Biannually & 14 & 13.5 \\
Total & 104 & 100.0
\end{tabular}

Source: Field survey, 2016

\section{Amount of vegetable produced in the study area}

Table 5 shows that Amaranthus ranked 1st is the most produced vegetable in the study area with a mean of 3.4301 . It is majorly produced at $51-75 \mathrm{~kg}$ by $29.2 \%$ farmers. Jute, ranked 2 nd is produced majorly at $26-50 \mathrm{~kg}$ by $38.3 \%$ of the farmers surveyed. Furthermore, Celosia is least produced by $16.7 \%$ of the farmers at $\geq 76 \mathrm{~kg}$. Okra is mostly produced by $22.5 \%$ of the farmers at $51-75 \mathrm{~kg}$ while pepper is produced at $0-25 \mathrm{~kg}$ by a few of the farmers $(4.2 \%)$. Vegetables such as tomato, fluted pumpkin and onion ranked 7th, 8th, 9th respectively. This showed that they are produced at a lower rate when compared to the other vegetables grown in the study area. 
Table 5: Quantity/ha of vegetable produced in the study area

\begin{tabular}{|c|c|c|c|c|c|c|}
\hline $\begin{array}{l}\text { Types of } \\
\text { vegetables } \\
\text { planted }\end{array}$ & $0-25 \mathrm{~kg}$ & $26-50 \mathrm{~kg}$ & $51-75 \mathrm{~kg}$ & $\geq 76 \mathrm{~kg}$ & Mean & $\begin{array}{c}\text { Ran } \\
k\end{array}$ \\
\hline Amaranthus & $\begin{array}{r}25(20.8 \% \\
)\end{array}$ & $31(25.8 \%)$ & $35(29.2 \%)$ & $25(20.8 \%)$ & $\begin{array}{r}3.430 \\
1\end{array}$ & $1^{\text {st }}$ \\
\hline Celosia & $\begin{array}{r}27(22.5 \% \\
)\end{array}$ & $32(26.7 \%)$ & $29(24.2 \%)$ & $20(16.7 \%)$ & $\begin{array}{r}3.000 \\
0\end{array}$ & $3^{\text {rd }}$ \\
\hline Fluted pumpkin & $6(5.0 \%)$ & $34(28.3 \%)$ & $21(17.5 \%)$ & $3(2.5 \%)$ & $\begin{array}{r}2.486 \\
2\end{array}$ & $8^{\text {th }}$ \\
\hline Okra & $9(7.5 \%)$ & $20(16.7 \%)$ & $27(22.5 \%)$ & $25(20.8 \%)$ & $\begin{array}{r}2.839 \\
5\end{array}$ & $4^{\text {th }}$ \\
\hline Pepper & $5(4.2 \%)$ & $20(16.7 \%)$ & $23(19.5 \%)$ & $21(16.7 \%)$ & $\begin{array}{r}2.576 \\
9\end{array}$ & $5^{\text {th }}$ \\
\hline Jute & $\begin{array}{r}14(11.7 \% \\
)\end{array}$ & $46(38.3 \%)$ & $31(25.8 \%)$ & $18(15.0 \%)$ & $\begin{array}{r}3.011 \\
2\end{array}$ & $2^{\text {nd }}$ \\
\hline Tomato & $6(5.0 \%)$ & $21(17.5 \%)$ & $25(20.8 \%)$ & $10(8.3 \%)$ & $\begin{array}{r}2.388 \\
9\end{array}$ & $7^{\text {th }}$ \\
\hline Onion & $2(1.7 \%)$ & $5(4.2 \%)$ & $14(11.7 \%)$ & $9(7.5 \%)$ & $\begin{array}{r}2.328 \\
1\end{array}$ & $9^{\text {th }}$ \\
\hline Other crops planted & $4(3.3 \%)$ & $14(11.7 \%)$ & $13(10.8 \%)$ & $30(24.6 \%)$ & $\begin{array}{r}2.517 \\
2\end{array}$ & $6^{\text {th }}$ \\
\hline
\end{tabular}

Source: Field survey, 2016

\section{Constraints to the use of organic fertilizer in the study area}

The constraints to the use of organic fertilizer were identified in the study area and ranked to determine the most important of these constraints as presented in Table 6 . The table revealed that majority of the respondents $(94.2 \%)$ had offensive odour as the major constraint to using organic fertilizer, this conforms to Ajewole (2010) that the offensive odour makes transportation and handling difficult. Difficulty in transporting, is the next major constraint to the use of organic fertilizer by most of the respondents $(86.7 \%)$, this stems from the bulky nature of organic fertilizer as more labour is required to load and unload the fertilizer from trucks. Stress of composting is the 3rd ranked constraint to using organic fertilizer. Also, need for drying, ranked 4th is a constraint to using organic fertilizer to an average $(50.0 \%)$ of the respondents, the above is in agreement with Ajewole (2010) that offensive odour, difficulty in 
transporting and doubtful efficacy are the constraints mitigating against the use of organic fertilizer. Furthermore, inadequate space limits $49.2 \%$ of the respondents from using organic fertilizer. Lower output from the use of organic fertilizer is a constraint to using organic fertilizer to $31.7 \%$ of the respondents in the study area. This can be an advantage and disadvantage at the same time because while the slowness may decrease current output, the long lasting effect of organic fertilizer due to the slow release of minerals may help decrease future cost of production and increase future output (Alimi et al., 2006).

Table 6: Constraints to the use of organic fertilizer in the study area

\begin{tabular}{llrrr}
\hline Major constraints to the use of organic fertilizer & \multicolumn{2}{c}{ Responses } & \multirow{2}{*}{ Rank } \\
\cline { 3 - 3 } & $\mathrm{N}$ & Percent & \\
\hline 1. Offensive odour & 113 & $94.2 \%$ & $1^{\text {st }}$ \\
2. Difficulty in transporting & 104 & $86.7 \%$ & $2^{\text {nd }}$ \\
3. Stress of composting & 68 & $56.7 \%$ & $3^{\text {rd }}$ \\
4. Need for drying & 60 & $50.0 \%$ & $4^{\text {th }}$ \\
5. Inadequate storage space & 59 & $49.2 \%$ & $5^{\text {th }}$ \\
6. Gives lower output & 38 & $31.7 \%$ & $6^{\text {th }}$ \\
7. Doubtful efficacy & 37 & $30.8 \%$ & $7^{\text {th }}$ \\
8. Not readily available & 36 & $30.0 \%$ & $8^{\text {th }}$ \\
9. Slow effect on vegetables & 27 & $22.5 \%$ & $9^{\text {th }}$ \\
10. Preference of inorganic fertilizer & 12 & $10.0 \%$ & $1^{\text {th }}$ \\
\hline
\end{tabular}

Source: Field survey, 2016 *Multiple responses

A few of the vegetable farmers (30.8\%), also take doubtful efficacy as a constraint to using organic fertilizer because it is difficult to ascertain the nutrient composition of organic fertilizer, thereby making it difficult a bit to know the exact amount to apply (Jokella et al., 2004). Organic fertilizer is not readily available to some of the respondents $(30.0 \%)$ and this is a constraint to using organic fertilizer for them. Slow effect on the vegetables is a constraint to using organic fertilizer, affecting few of the respondents (22.5\%). Lastly, preference of inorganic fertilizer ranked 10 th as a constraint to only a number of the respondents $(10.0 \%)$. 


\section{Hypothesis testing}

$\mathrm{H}_{0}$ : there is no significant relationship between the socio-economic characteristics of respondents and the extent of use of organic fertilizer.

Table 7: Pearson Product Moment Correlations (PPMC) Table

\begin{tabular}{lccl} 
Variable & \multicolumn{3}{c}{ Extent of use of organic fertilizer } \\
\cline { 2 - 4 } & $\mathrm{R}$ & $(\mathrm{p}$-value $)$ & Remark \\
\hline Age & 0.484 & 0.070 & Significant \\
Educational level & 0.568 & 0.028 & Significant \\
& & & \\
$\begin{array}{l}\text { Years of farming } \\
\text { experience }\end{array}$ & 0.356 & 0.049 & Significant \\
$\begin{array}{l}\text { Farm size } \\
\text { Household size }\end{array}$ & 0.054 & 0.081 & Not significant \\
Source: Fidd & 0.124 & 0.650 & Not significant
\end{tabular}

Source: Field survey, 2016 Correlation is significant at 0.05 (2-tailed)

The results of Pearson product moment correlation analysis showed that age, educational level and years of farming experience were significantly related to the extent of use of organic fertilizer as was similarly found by Adebayo and Adekunle (2016). This implies that the older farmers tend to use more organic fertilizer than the younger ones. A reason for this could be that due to their age and experience gathered by older farmers, they already know the benefits of the usage of organic fertilizers in vegetable farming. The analysis further showed that educational level is significant. It is expected that educated farmers would know the importance of organic fertilizers over the use of inorganic fertilizers as also noted in the work of Ajewole (2010). Thus, this result confirms that the higher the level of education the more the farmers utilize organic fertilizer. Years of farming experience is also significant. Farmers with more experience tend to use organic fertilizer than the less experienced farmers. Again, this should be expected as vegetable farmers who have committed several years into vegetable farming should know the how, why, and when to apply organic fertilizer to vegetables on the farm.

\section{CONCLUSION}

The study concludes that vegetable farmers in the study area use organic fertilizer but the amount of vegetable produced is rather low. It was also found that the vegetable farmers in 
the study area prefer organic fertilizer to inorganic fertilizer even though they face major constraints like offensive odour and difficulty in transporting the organic fertilizers. The sampled farmers were also found to have low level of education. The yield of vegetable being produced is also not enough to feed the population. Given that organic fertilizers have been observed to be slow acting therefore it takes the soils a longer period to fully break them down, so there is the risk of over application by farmers. Hence the following recommendations are made so as to possibly increase the amount of vegetables being produced by the farmers in the study area.

\section{RECOMMENDATIONS}

The study, therefore, offers a number of recommendations based on the objectives of the study. Given that the study recorded that there is a tendency of over application of fertilizer, the use of organic fertilizers should subsequently be supervised by the Environmental Protection Agency (EPA) and other Government Agencies to ensure that excessive levels are not applied, as this could result in environmental pollution in the long run if left unsupervised. Entrepreneurs and investors should also be motivated by Government through tax exemptions and subsidies among other things to invest in setting up composting sites as composting helps remove some of the constraints noted in the study for example odour and the need for drying up manure before application as this consumes time. Research Institutes and other relevant agricultural organizations should also devise ways of reducing the bulky nature as well as the offensive odour associated with organic fertilizers. Government through extension agents and agencies should provide incentives to the farmers to ensure expansion of production and supply of vegetables to markets for consumers through training on proper use and application of organic fertilizer for vegetable production so as to ultimately increase the yield of farmers.

\section{REFERENCES}

Adebayo, S. A. and Adekunle, O. A. (2016). Socio-economic status of women in group membership in selected areas of Kwara State, Nigeria. Agrosearch 16 (1): 57- 64.

Adrian C., David W., Carl W., Jean R., Dan G., (2014). Organic fertilizer. http://www.ext.colostate.edu/mg/gardennotes/234.html; Retrieved 15 September, 2014.

Ajewole, O. C. (2010). Farmer's response to adoption of commercially available organic fertilizers in Oyo state, Nigeria. African Journal of Agricultural Research, 5(18): 2497-2503, 18 September, 2010. ISSN 1991-637X @2010 Academic Journals 
Alimi, T, Olubode-Awosola, O. O. \& Idowu, E. O. (2006). Economic Rationale of Commercial Organic Fertilizer Technology in vegetable production in Osun state Nigeria. Journal of Applied Horticulture, 8(2): 159-164, July-December.

Carroll \& Salt, Steven B, and Steven D. (2004). Ecology for gardeners. Cambridge: Timber press, 420p.

Defoer, T. (2002). Learning about methodology development for integrated soil fertility management, Agricultural Systems, 73: 57-81.

FAO (2011). FAO Statistical Pocketbook, world food and agriculture. www.faostat.fao.org

Heinrich D. Manfred D., Ralf V., Martin E.T., Reinhold G., Gunter S., 2009. 'Fertilizers, 2.Types' in Ullmann's Encyclopedia of Industrial Chemistry, Wiley- $\mathrm{VCH}$, Weinheim. Ibeawuchi, I.I., Okoli, N.A., Alagba, R. A., Ofor, M. O., Emma-Okafor, L. C., Peter-Onoh, C.A. \& Obiefuna, J.C., (2015). Fruit and Vegetable Crop Production in Nigeria: The Gains, Challenges and the Way Forward. Journal of Biology, Agriculture and Healthcare, 5 (2) ISSN: 2224-3208 (Paper) ISSN 2225-093X (Online).

Jokella, B., Magdoff, F., Bartlett, R., Bosworth, S., \& Ross, D. (2004). Nutrient recommendations for field crops in Vermont. BR 1390 (University of Vermont Cooperative Extension, 2004).

Matanmi B.M, G.B Adesiji, E,M Olasheinde and F.O Oladipo (2011) Assessment of Usage of Upgraded indigenous Shea butter Processing technology by Women Processors in Kwara State, Nigeria. Agrosearch, 11(1\&2): 19-30.

NBS - National Bureau of Statistics 2006. Core welfare indicator questionnaire Survey, Nigeria, 2006. Abuja.

Obalola, T. O. and Tanko, L. (2016). Comparative economic analysis of irrigated and rain-fed spinach (Amaranthus cruentus) production in Minna Metropolis, Niger State, Nigeria. Agrosearch, 16 (1): 87-94.

Odhiambo, J. J. O. \& Madangini, V. N. (2008). An Assessment of The use of Mineral and Organic Fertilizers by Smallholder Farmers in Vhembe District, Limpopo Province, South Africa. African Journal of Agricultural Research, 3 (5), 357-362, May, 2008. ISSN 1991- 637X @ 2008 Academic Journals.

Rigby, D., \& Caceres, D., 2001, "Organic farming and the sustainability of agricultural systems", Agricultural Systems, 68 (1): 21-40.

Shing-Jy, J. T., \& Hsiao-Feng, L. (2003). "Handbook of Vegetable Preservation and Processing" Edited by Y. H. Hui, Sue Ghazala, Dee M. Graham, K. D. Murrell, and Wai-Kit Nip CRC Press. 
Tindall, H. D. (1984). Vegetables in Tropics. Macmillan Education Ltd. London. 387p.

US Environmental Protection Agency (EPA), 2013. 'Organic Fertilizers http://www.epa.gov/agriculture/tfer.html Retrieved 14th September, 2015

Verena S., Navin R., Jonathan A.F. (2012). Comparing the yields of organic and conventional agriculture. Nature, 2012 DOI: $10.1038 /$ nature11069

Wilfried Werner, 2002. 'Fertilizer, 6. Environmental Aspects' Ullmann's Encyclopedia of Industrial Chemistry, Wiley-VCH, Weinheim. 